\title{
IMPORTANCE OF REPUTATION IN THE ASSESSMENT OF CORPORATE SOCIAL RESPONSIBILITY
}

\author{
Lukáš Vartiak ${ }^{1}$
}

\begin{abstract}
Successful organizations need to be profitable and also recognized by the general public. Therefore, organizations are becoming more socially responsible. Socially responsible actions are positively perceived. These actions together are molding the organization's reputation. The purpose of this study was to highlight the importance of reputation in the assessment of corporate social responsibility (CSR). The purpose is realized by the secondary research, which consists of parsing the worldwide CSR ranking. Analysis, comparison, and selection are methods used in the secondary research. As the main finding, it may be considered that connections between reputation and CSR exist in three dimensions. Information from the secondary research confirms the importance of reputation in the CSR assessment. Recommendations arising from this study are that organizations should act socially responsible and they should inform the general public about their CSR performance, so that they can obtain a competitive advantage.
\end{abstract}

JEL Classification Numbers: M10, M14, Z13, DOI: http://dx.doi.org/10.12955/cbup.v3.587

Keywords: reputation, corporate social responsibility, consumers, general public

\section{Introduction}

In the $21^{\text {st }}$ century, the popularity of corporate social responsibility (CSR) has been increasing. Organizations and public media caused the popularization of this concept. Society's consciousness on the effects of organizations' behavior has risen with increased awareness on economic, societal, environmental, ethical, and political issues in a global range. Every organization is also making efforts to succeed; the success of organization depends on many factors (Jankalová, 2012; Jankal, 2014). Socially responsible organizations have a competitive advantage. But, it is not enough just to be socially responsible. It is necessary to ensure the general public knowledge. Every organization is, in fact, externally assessed by its actions, which promote its reputation. Therefore, the concept of CSR and reputation are deeply connected.

For clarification, building a good reputation of organization can take years. On the other hand, good reputation can be taken away in months or even in days by one negative activity, especially socially or environmentally related. Thus, the intention to limit negative activities, and to promote CSR activities, might be more beneficial to every organization. CSR initiatives can become costly for the organization, but the increasing involvement in building positive reputation might eventually increase the organization's revenues (Minor \& Morgan, 2011).

The purpose of this study was to highlight the importance of reputation in the assessment of CSR. It is divided into five parts. Introduction represents input to the problem. Theoretical background addresses the definition of reputation and describes relationship between reputation and CSR. Methodology describes methods used in the secondary research including analysis, comparison, and selection. Results part includes secondary research that consists of CSR ranking conducted by the world's leading reputation consulting organization. Conclusion and recommendations consists of the evaluation of the results from the secondary research, which fulfill the purpose of the study. It also includes recommendations for the future.

\section{Theoretical background}

Basically, reputation is a combination of reality and perception. Reality is represented by economic and social performance, and perception is represented by performance perceived by key stakeholders (Hemphill, 2006). According to Friedman (2009), an organization's reputation is a perceptual

\footnotetext{
${ }^{1}$ Lukáš Vartiak, Faculty of Operation and Economics of Transport and Communications, University of Žilina, lukas.vartiak@fpedas.uniza.sk
} 
representation of its past actions and future prospects. He further refers reputation as organizational asset that is important to its competitiveness. Reputation indeed serves as a tool to compare the organization to its competitors. Highhouse, Brooks, \& Gregarus (2009) described an organization's reputation as global and temporally stable judgment about organization that is shared by multiple stakeholders. According to Bovenkerk, Siegel, \& Zaitch (2003), an organization's reputation is a soft concept. It is the overall judgment of the organization that is held by its external stakeholders. Their judgment is based on the organization's past actions and expected future actions. Stakeholders' experiences and preferences in dealing with the organization may be different depending on the information they obtained from others.

Walker (2010) identified five key attributes that are emphasized in the definition of reputation:

1. reputation is based on perceptions;

2. reputation is the aggregate perception of all stakeholders;

3. reputation is comparative;

4. reputation can be positive or negative;

5. reputation is stable and enduring.

Walker (2010) further presented these attributes as moving from pre-action, through action, to postaction. An organization's reputation is built in a pre-action stage. It includes gaining organization's legitimacy and cultural support. Action stage is dedicated to maintenance and defense of organization's reputation. At the post-action stage, organization benefits from its strongly built reputation.

Organization's reputation is developed through two sources: experience and information. Favorable organization's reputation requires effective communication effort from the organization and admirable identity. Usually, organization can mold its reputation over many years and even decades (Gottschalk, 2010).

Number of authors have already explained the relationship between reputation and CSR. According to Highhouse et al. (2009), determinants of an organization's reputation are social capital, knowledge, product development, diversification, advertising, media exposure, public relations, word of mouth, and CSR policy. Castelló \& Lozano (2009) described a three-posture approach that aims to help managers clarify where they are in terms of CSR. This approach can be useful for managers in analyzing the current situation of organizations and helping them develop CSR further. The postures are:

1. Risk management posture: In the first posture, CSR is seen as a tool to protect reputational value of organization. Organization measures and controls environmental and social potential issues by social forecasting and preparing for social response.

2. Integrated posture: In the second posture, organization tries to fulfill society's increasing expectations. It includes changing its business model to include new social and environmental responsibilities.

3. Citizenship posture: The third posture is described as one in which organization is open to integrating social issues as part of its responsibilities. Citizenship has a role in leading social issues and transforming organization's business model.

According to Griffin (2008), an organization's reputation is the result of its ability to manage issues, crises, and CSR. Siltaoja (2006) pointed out that CSR and reputation are deeply connected. According to his study, it is not possible to evaluate corporate actions in the framework of reputation without 
knowing what people understand by CSR. Figure 1 shows that reputation of an organization is constructed when its actions are assessed by its various stakeholder groups.

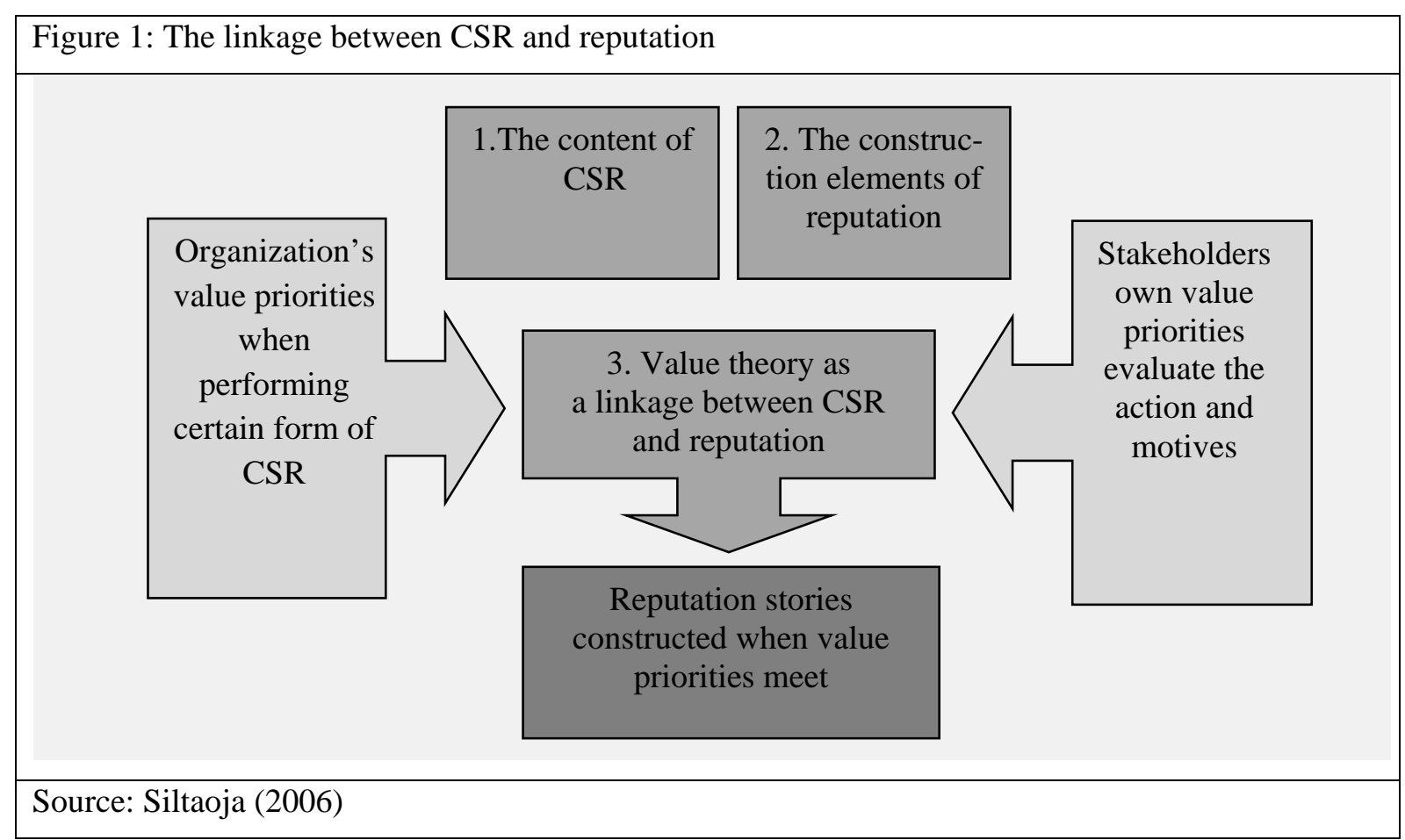

\section{Methodology}

The purpose of this study was to highlight the importance of reputation in the assessment of CSR. At the beginning, it was necessary to describe the term reputation and to delineate the relationship between reputation and CSR. Next step is secondary research by which the achievement of the purpose is realized. It consists of interpretation of the results from CSR RepTrak®. CSR RepTrak ${ }^{\circledR}$ is CSR ranking conducted by the world's leading reputation consulting organization-Reputation Institute. Analysis, comparison, and selection are methods used in the secondary research. The results of secondary research, thus, bring information that confirms the importance of reputation in the CSR assessment. This information also creates the opportunity to make recommendations for the future.

\section{Results}

Over the past decade, multiple standards, rankings, and performance measurement systems have been developed to measure and rate the condition of CSR in organizations. The need has arisen to create an instrument that measures the gap between the actual CSR performance of organizations and the status of CSR perceived by the general public (Reputation Institute, 2014). Reputation Institute (RI), the world's leading reputation consulting organization, measures the reputations of more than 1000 of the world's largest companies in their home countries. Since 2011, RI has carried out these studies each year. The outcome of the studies is an annual roster of the top 100 organizations (Reputation Institute, 2011). RI's RepTrak ${ }^{\circledR}$ model measures the emotional perceptions and the rational explanations of an organization's reputation. Rational explanations are captured within the seven dimensions of reputation: Products and Services, Innovation, Workplace, Governance, Citizenship, Leadership, and Financial Performance (Reputation Institute, 2014).

RI's CSR RepTrak ${ }^{\circledR}$, the study that ranks 100 most reputable organizations, is based on their CSR reputation. CSR reputation is measured by an organization's performance in three of the seven reputation dimensions: Citizenship, Governance, and Workplace. RI’s CSR RepTrak ${ }^{\circledR}$ ranking is 
based on research from these 15 global markets: Australia, Brazil, Canada, China, France, Germany, India, Italy, Japan, Mexico, Russia, South Korea, Spain, UK, and USA (Reputation Institute, 2014).

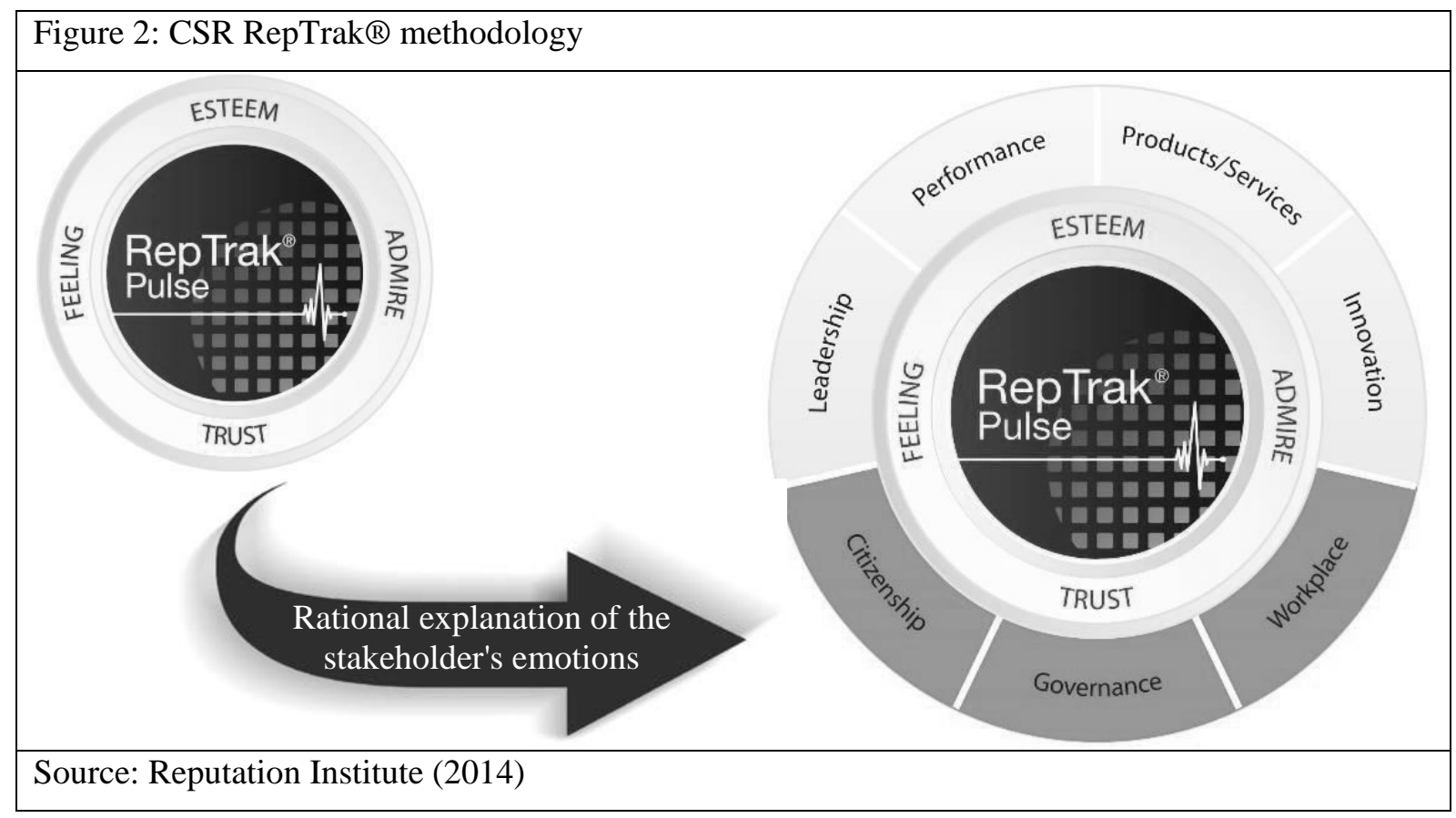

CSR RepTrak ${ }^{\circledR}$ score reflects an organization's performance in Citizenship, Governance, and Workplace dimensions. CSR reputation of organization is rated on a scale from 0 to 100 (Reputation Institute, 2014). The task of the respondents is to rate each survey question on a scale from 1 to 7 , where " 1 ” means "strongly disagree” and "7” means "strongly agree.” Aggregate value of individual research questions gives an overall evaluation of CSR reputation of the organization. Rating scale is summarized in Table 1.

\begin{tabular}{|l|l|}
\hline \multicolumn{1}{|c|}{ Table 1: CSR Reputation Score } & \multicolumn{1}{c|}{ Condition } \\
\hline Above 80 & Excellent / Top Tier \\
\hline $70-79$ & Strong / Robust \\
\hline $60-69$ & Average / Moderate \\
\hline $40-59$ & Weak / Vulnerable \\
\hline Below 40 & Poor / Bottom Tier \\
\hline Source: Reputation Institute (2013) & \\
\hline
\end{tabular}

Organizations with better CSR reputation have a much greater ability to foster desired supportive behaviors among consumers. It includes buying their products, recommending their organization, and saying something positive about it, or trusting the organization to always do the right thing. Relations between mentioned consumers' behaviors and CSR scores are displayed in Figure 3 (Reputation Institute, 2014).

According to Figure 3, Excellent/Top Tier organization would be recommended to others by $89 \%$ of the consumers. Also, $89 \%$ of the consumers would buy its products or services. $91 \%$ of the consumers would say something positive about it, and $90 \%$ of the consumers would trust the organization to do the right thing. On the other hand, Poor/Bottom Tier organization would be recommended to others by only $6 \%$ of the consumers, and only $7 \%$ of the consumers would buy its products or services. Just $5 \%$ 
CBU I NTERNATIONAL CONFERENCE ON I NNOVATION, TECHNOLOGY TRANSFER AND EDUCATION

of the consumers would say something positive about the organization, and only $5 \%$ of the consumers would trust it to do the right thing (Reputation Institute, 2014).

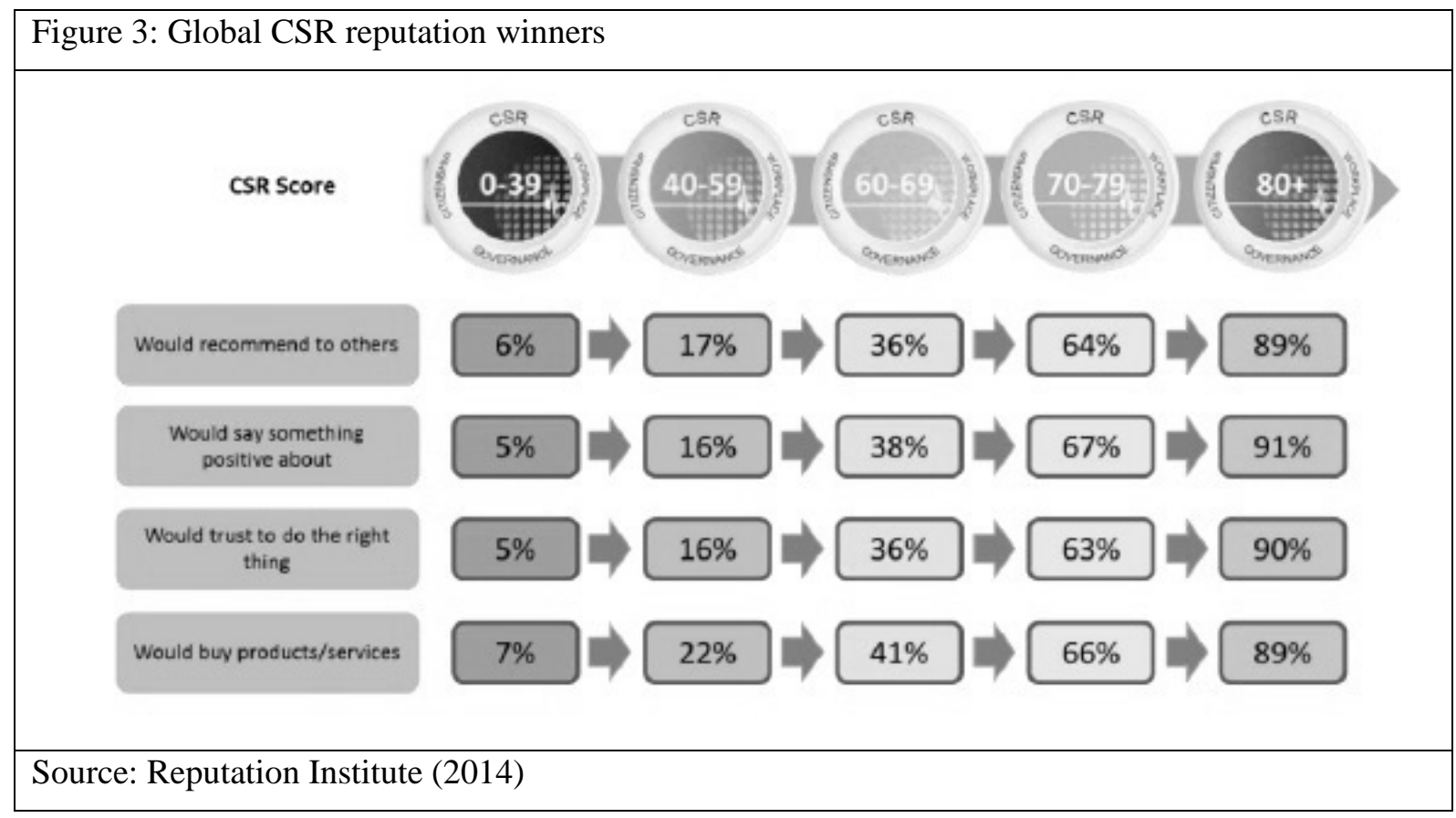

The 2014's top organizations based on their CSR reputation came from the IT, automotive, consumer goods, and media/entertainment industries. The highest score in the 2014 Global CSR RepTrak® ranking was 72.7. It was earned by Google. The Top 100 ranking is concluded by Zara. Its score was 61.8. Figure 4 shows the scores of the 10 most successful organizations (Reputation Institute, 2014).

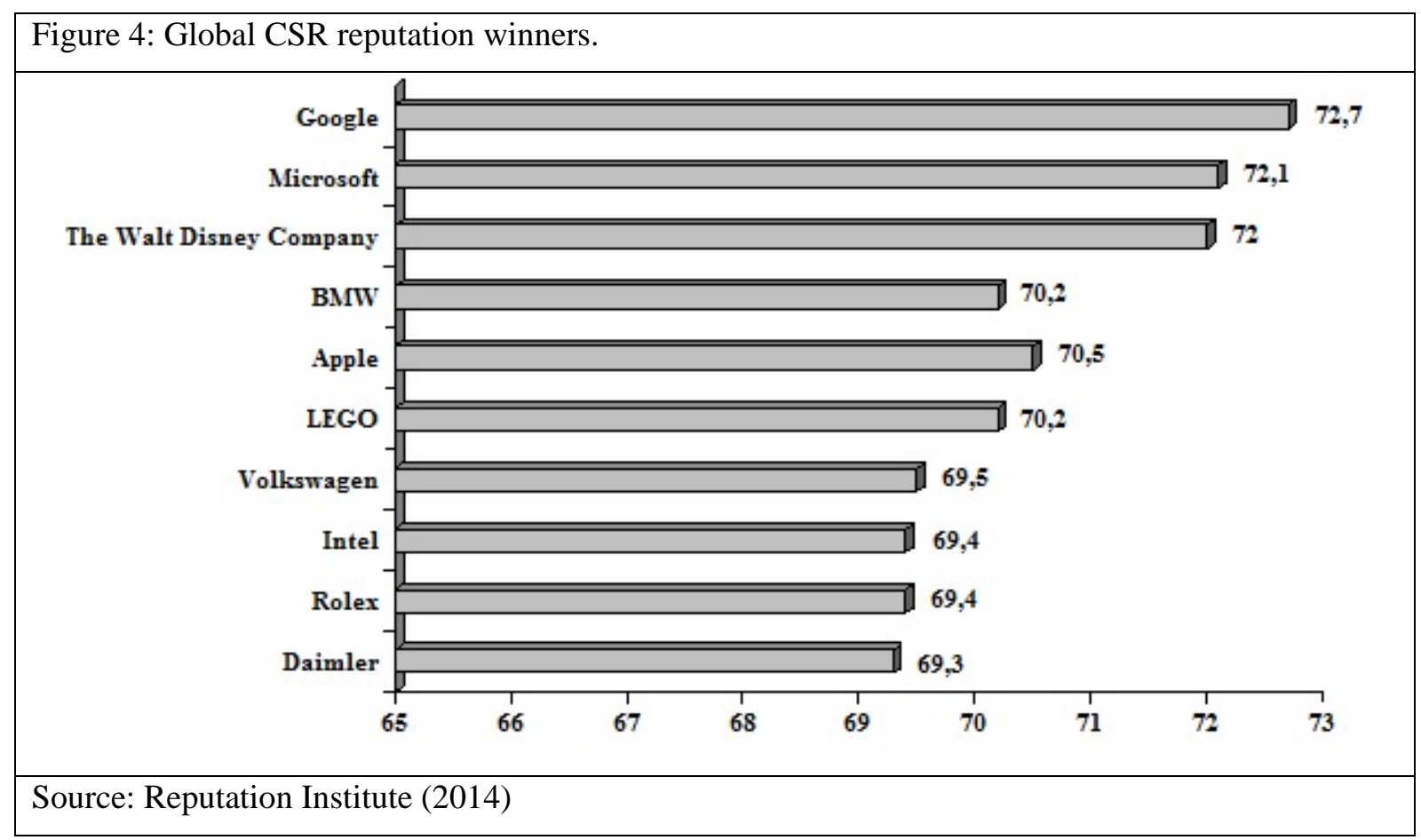

The ranking also evaluates the most reputable organizations within each of the three CSR dimensions of reputation. Results of 2014 Global CSR RepTrak ${ }^{\circledR}$ ranking are as follows (Reputation Institute, 2014): 
- Governance dimension: Apple, BMW, Google, LEGO, Microsoft, Rolex, The Walt Disney Company, and Volkswagen.

- Citizenship dimension: Google, Microsoft, and The Walt Disney Company.

- Workplace dimension: Google and Microsoft.

Each group mentioned above includes organizations with similar reputation in a specified dimension (Reputation Institute, 2014).

Interest in CSR by global stakeholders is growing. Increasing public awareness of an organization's CSR performance is key to maximizing the return on investment in CSR and sustainability. 2014 Global CSR RepTrak ${ }^{\circledR}$ ranking also provided information that organizations are not effective in communicating their CSR performance. Despite the significant financial and personal investment in CSR, most organizations still struggle to find the best way of communicating their CSR strategies to the general public. Consumers across 15 countries remain highly uncertain about organizations' CSR performance. For example, $62 \%$ of the consumers in the UK, $51 \%$ of the consumers in the USA, $41 \%$ of the consumers in China, 37\% of the consumers in Brazil, and 36\% of the consumers in India are neutral on or uncertain whether an organization is achieving good results in the field of CSR concept (Reputation Institute, 2014).

\section{Conclusion and recommendations}

Nowadays, general public is becoming more interested in issues such as social responsibility, sustainability, and transparency. As a result, organizations are trying not only to make a profit, but also to care for the public good. All the actions of organizations are involved in the formation of their reputation. Implementing a CSR strategy is one of the leading ways to boost reputation of any organization. The purpose of this study was to highlight the importance of reputation in the assessment of CSR. Relationship between these two concepts was examined from the theoretical standpoint and also from the practical standpoint. Reputation Institute (RI), the world's leading reputation consulting organization, has developed a methodology for evaluating the performance of CSR through reputation. With this methodology, it is possible to identify the consumers' attitudes towards Citizenship, Governance, and Workplace dimensions of organizations. The results show that CSR performance is determined by a number of factors that influence whether the consumers would recommend organization to others, would say something positive about it, would trust it to do the right thing, and would buy its products or services. The organization with the highest CSR rating in 2014 was Google, which also received an excellent rating in all three monitored dimensions. Another very successful organizations are Microsoft and The Walt Disney Company. However, the difference in a score between the $1^{\text {st }}$ and the $100^{\text {th }}$ organization was only 10.9 points. This means that only exceptional organizations are included in the Top 100 ranking. However, despite the excellent results in the field of CSR, most organizations still struggle to find the effective way of communicating their CSR strategies to the general public. It is bewildering because organizations are making significant financial and personal investment in CSR; and, from the perspective of consumers, it still is not enough. Recommendations for organizations are to be socially responsible and to use social responsibility as a competitive advantage. To fulfill these two goals, it is important to find a balance between organization-wide implementation of the CSR concept and informing the general public about CSR performance through external communications.

\section{Acknowledgements}

The paper was conducted within the projects VEGA 1/0916/15 and VEGA 1/0895/13. 


\section{References}

Bovenkerk, F., Siegel, D., \& Zaitch, D. (2003). Organized crime and ethnic reputation manipulation, Crime, Law and Social Change, 39, 23-38.

Castelló, I., \& Lozano, J. (2009). From risk management to citizenship corporate social responsibility: analysis of strategic drivers of change. Corporate Governance, 9(4), 373-385.

Friedman, B. A. (2009). Human Resource Management Role Implications for Corporate Reputation. Corporate Reputation Review, 12(3), 229-244.

Gottschalk, P. (2010). Policing Cyber Crime. London: Ventus Publishing ApS, 2010.

Griffin, A. (2008). New Strategies for Reputation Management: Gaining Control of Issues, Crises and Corporate Social Responsibility. London: Kogan Page, 2008.

Hemphill, T. A. (2006). Corporate internal investigations: balancing firm social reputation with board fiduciary responsibility. Corporate Governance, 6(5), 635-642.

Highhouse, S., Brooks, M. E., \& Gregarus, G. (2009). An Organizational Impression Management Perspective on the Formation of Corporate Reputations. Journal of Management, 35(6), 1481-1493.

Jankal, R. (2014). The role of innovation in the assessment of the excellence of enterprise subjects. Procedia - social and behavioral sciences, 109, 541-545.

Jankalová, M. (2012). Business Excellence evaluation as the reaction on changes in global business environment. Procedia Social and Behavioral Sciences, 62, 1056-1060.

Minor, D., \& Morgan, J. (2011). CSR as Reputation Insurance: Primum Non Nocere. California Management Review, 53(3), 40-59.

Reputation Institute. (2011). Google, Apple, Disney, BMW and LEGO are the world's most reputable companies according to consumers across 15 countries. New York: Reputation Institute, 2011.

Reputation Institute. (2013). 2013 - Global CSR RepTrak ${ }^{\circledR}$ 100. Top Line Report: The Best CSR in the World (Reputation study with Consumers in 15 Countries). New York: Reputation Institute, 2013.

Reputation Institute. (2014). 2014 Global CSR RepTrak ${ }^{\circledR}$ 100: Annual Corporate Social Responsibility (CSR) Reputation Ranking. New York: Reputation Institute, 2014.

Siltaoja, M. E. (2006). Value Priorities as Combining Core Factors Between CSR and Reputation - A Qualitative Study. Journal of Business Ethics, 68, 91-111. 